\title{
RECOGNITION OF FOREIGN DECREES OF DIVORCE IN CANADA
}

\author{
JOHN R. RATHWELL*
}

Historically, the test for recognition of foreign decrees of divorce in Canada has been the domicile of the parties at the time of the commencement of the proceedings. ${ }^{1}$ The purpose of this paper is to consider, in the light of recent developments in English case law, whether in addition to that test we now have a new rule for recognition founded on section two of the Divorce Jurisdiction Act. ${ }^{2}$

Section two of that Act reads as follows:

A married woman who either before or after the passing of this Act has been deserted by and has been living separate and apart from her husband for a period of two years and upwards and is still living separate and apart from her husband may, in any one of those provinces of Canada in which there is a court having jurisdiction to grant a divorce a vinculo matrimonii, commence in the court of such province having such jurisdiction proceedings for divorce $a$ vinculo matrimonii praying that her marriage may be dissolved on any grounds that may entitle her to such divorce according to the law of such province, and such court shall have jurisdiction to grant such divorce provided that immediately prior to such desertion the husband of such married woman was domiciled in the province in which such proceedings are commenced.

The first and obvious conclusion to be drawn as to the effect of this provision is that it expressly creates a new domestic jurisdiction for those courts in Canada which exercise jurisdiction in divorce. Those courts are now permitted to entertain proceedings in divorce where the domicile of the husband immediately preceding the commencement of two or more years of desertion was within the court's jurisdiction. That is all that the legislation expressly does. However, does it implicitly alter our conflict rules for the recognition of foreign decrees?

It is certain that it does do so in one respect, in so far as it is now incumbent upon the courts of all the provinces ${ }^{3}$ of Canada to recognize divorces granted in sister provinces pursuant to section two of the Act. But what is the status in Canada of divorce decrees granted in foreign countries where the husband was domiciled in that foreign jurisdiction not at the commencement of the proceedings but immediately prior to two or more years desertion?

Some writers contend ${ }^{4}$ that section two implicitly creates a new rule for the recognition of foreign decrees. The tenor of the rule is that our courts will not recognize a divorce granted by a foreign court if the husband was domiciled within the jurisdiction immediately preceding the commencement of two or more years of desertion. It is readily apparent

* B.A., LL.B., (Alta.)

1 The Canadian cases have adopted the test laid down in Le Mesurier v. Le Mesurier, [1895] A.C. 517: see Stephens v. Falchi, [1938] S.C.R. 354, [1938] 3 D.L.R. 590.

2 (Can.) 1930, c. 15.

8 Newfoundland may be an exception, as the Act has not as of yet been declared in force pursuant to the British North America Act, 1949 No. 1. (Imp.) 1949, c. 22. Reference should be made to Kennedy, Recognition of Foreign Divorces in Newfoundland, 32 Can. Bar Rev. 211.

- See Griswold, Divorce Jurisdiction and Recognition of Divorce Decrees-A Comparative Study 25 Aust. L.J. 248 (1951): Kennedy, Recognition of Foreign Divorce and Nullity Decrees 35 Can. Bar Rev. 628 (1957), also 31 Can. Bar Rev. 799; Wickens, Correspondence 23 Can. Bar Rev. 244 (1945). 
that this contention proceeds, in effect, on the principle that our recognition rules should mirror our domestic rules for jurisdiction. Those who support this proposition found themselves upon the recent decision of the English Court of Appeal in Travers v. Holley, ${ }^{5}$ which will be discussed extensively in the latter part of this paper.

However, there is by no means unanimity of opinion on this question. The courts of Scotland ${ }^{\mathbb{a}}$ and the state of Victoria ${ }^{i}$ have shown themselves unprepared to hold that the changing of domestic rules of jurisdiction automatically change conflict rules to the same extent. It is argued that the domicile of the parties at the commencement of the proceedings, as the test for recognition, is so firmly entrenched in our law, that it would require an express legislative enactment for the creation of any other test.

It is submitted that, in attempting to answer this question, the logical manner in which to proceed ${ }^{8}$ is to examine the common law principles as they existed before the passing of any statute changing domestic jurisdiction. For if it is contended that our rules for the recognition of foreign decrees automatically change, when the basis of exercising domestic jurisdiction changes that contention must be founded on some preexisting principle. An attempt will therefore be made to ascertain those common law principles, to examine critically the relevant cases in the light of these principles, and to suggest the proper approach for the Canadian courts to take in regard to this matter.

The case of LeMesurier v. LeMesurier ${ }^{9}$ is pointed to by the leading authorities ${ }^{10}$ on the conflicts of laws as affirmatively establishing that the test for domestic jurisdiction as well as for the recognition of foreign decrees is the domicile of the parties at the time of the commencement of the proceedings. That case was concerned with the domestic jurisdiction of the courts of Ceylon. Therefore, it was not a binding decision for English courts; and what was said in relation to recognition was, as a consequence, strictly obiter. Despite this fact, the case has been uniformly relied upon in subsequent cases as settling the law in both these areas; and it has gone unquestioned since, both in England and in the Commonwealth countries. ${ }^{11}$ It is, therefore, not only appropriate but very necessary to see precisely what Lord Watson decided in that important case.

The District Court of Matara had granted a decree of divorce to an Englishman resident in Ceylon, as a member of the Ceylon Civil Service, but who was at all times domiciled in England. The Supreme Court reversed that decision on grounds which are unimportant for present purposes. The case was then appealed to the Privy Council.

Lord Watson, in delivering their Lordships' opinion, began by pointing out that, in order for the decree to be valid, the court's jurisdiction must have been based upon some municipal law or the general law of nations. There was no municipal law creating jurisdiction in the court in these circumstances; but it was alleged by counsel that the general

5 [1953] 2 All E.R. 794, 1953 P. 246.

6 Warden v. Warden, [1951] S.C. 508

7 Fenton v. Fenton, [1957] V.R. 17.

8 It is submitted that there has been a sparsity of clear thinking in this area by the courts and legal writers, which has led to unsound thinking.

9 Ante, n. 1.

10 Falconbridge, Essays on the Conflict of Laws, 727 (2d. ed. 1954); Cheshire, Private International Law, 394 (6th ed. 1961); Dicey, Conflict of Laws, 304 (7th ed. 1948).

11 E8., Canada: Stephens v. Falchi, [1938] S.C.R. 354. 
law of nations, as well as recognizing a decree of divorce granted where the parties were domiciled within the jurisdiction, also recognized divorces granted on the basis of matrimonial domicile. Matrimonial domicile was defined as a prolonged residence not sufficient to establish domicile as that term is ordinarily understood in English law. For this proposition counsel cited several Scottish and English cases. ${ }^{12}$

In his judgement, Lord Watson discredited those cases which suggested that ${ }^{13}$ members of the House of Lords had, in dicta, disagreed with such a proposition. It was his view that the judges in those cases had not paid enough heed to treaties on international law, which were "generally to be regarded as authoritative, in the absence of any municipal law to the contrary." 14 He cited those treatises for the principle that, in order for a divorce to be recognized in all civilized countries, the parties must have been domiciled in the jurisdiction at the time of the commencement of the proceedings.

What is important to note is that Lord Watson was not attempting to lay down any rule for the recognition of foreign decrees. All he was attempting to establish was that the rule for domestic jurisdiction according to the general law of nations was the domicile of the parties, and not that purported by counsel (i.e. matrimonial domicile). Therefore, since Ceylon had no municipal law determining this question, the law to be adopted was that of the general law of nations which prescribed the domicile of the parties as the true test. It is also significant that, although Lord Watson was only concerned with the law of Ceylon, because of the argument addressed to him, it was necessary for him to decide also what the English and Scottish law was. In doing so, it is now clear that he settled, if it was unsettled before, this area of the law of those countries.

However, it is not enough to consider the result of the case; it is essential to have regard to the reasons why Lord Watson thought the general law of nations should prevail in the absence of municipal law to the contrary. The obvious answer is that the divorce would then, according to the international treatises he cited, be recognised by all civilized countries; for, as he says at page 525: ,

... a decree of divorce a vinculo, pronounced by a Court whose jurisdiction is solely derived from some rule of municipal law peculiar to its own forum, cannot, when it trenches upon the interests of any other country to whose tribunals the spouses were amenable, claim extra-territorial validity.

It is here that we get at the crux of his reasoning. It is clear that in his opinion England, being a civilized country, would recognize decrees granted by courts entertaining actions on the basis of the parties being domiciled in the jurisdiction at the commencement of the proceedings. But he did not state that to be the only circumstance in which England or any other country would recognize a foreign decree of divorce. To the contrary, he said that a decree will not be recognized when it is based on rules "peculiar to its own forum." The logical inference is that it would be recognized by a country which exercised jurisdiction in the same circumstances. He could have acceded to counsel's argument and decided

12 Brodie v. Brodie, 2 Sw. \& Tr. 259; Jack v. Jack, 24 Court Sess. Cas. (2nd series) 462; Hume v. Hume, 24 Court Sess. Cas. (2nd Series) 1342.

18 Pitt v. Pitt, 1 Court Sess. Cas. (3rd Serles) 106, 4 Marcq. App. Cas. 627.

14 [1895] A.C. 517. 587 . 
that the true test for England and Ceylon was prolonged residence, despite the fact that this was not the general test of the law of nations. But in such a case the decree would only be recognized by countries that exercised jurisdiction in like circumstances. On the other hand, if he decided that the true test was domicile of the parties at the commencement of the proceedings, the divorce would be, to use his term, recognized "in all civilized countries." In holding as he did, he was making a policy decision; and this fact is reflected in the following words at page 540:

Their Lordships have in these circumstances, and upon these considerations, come to the conclusion that, according to international law, the domicile for the time being of the married pair affords the only true test of jurisdiction to dissolve their marriage. They concur without reservation, in the views expressed by Lord Penzance in Wilson v. Wilson which were obviously meant to refer, not to questions arising in regard to the mutual rights of married persons, but to jurisdiction in the mater of divorce: 'It is the strong inclination of my own opinion that the only fair and satisfactory rule to adopt on this matter of jurisdiction is to insist upon the parties in all cases referring their matrimonial differences to the Courts of the country in which they are domiciled. Different communities have different views and laws respecting matrimonial obligations, and a different estimate of the causes which should justify divorce. It is both just and reasonable, therefore, that the differences of married people should be adjusted in accordance with the laws of the community to which they belong, and dealt with by the tribunals which alone can administer those laws. An honest adherence to this principle, moreover, will preclude the scandal which arises when a man and woman are held to be a man and wife in one country and strangers in another.'

There can be no doubt, then, that Lord Watson was in no way attempting to decide what a particular country's rules for recognition of foreign decrees of divorce should be. He did indicate that, regardless of the basis upon which a court of any country exercised domestic jurdiction, that court would recognize foreign decrees of divorce granted by a different court in the jurisdiction of which the parties were domiciled because in recognizing such a decree it would then be adopting an international principle of law. However, this principle does not prevent the courts of a country from recognizing foreign divorces on additional grounds.

It is submitted that when Lord Watson used the phrase "peculiar to its own forum" he was indicating that a divorce granted under such rules would be recognized by the courts of other countries which granted divorces under like circumstances, but not otherwise. If that is so, then the general principle-that a country's recognition rules will reflect its domestic jurisdiction rules-must be implicit in Lord Watson's judgment. Surely, this is not straining the language of Lord Watson to an unbearable length. On the contrary, it is a perfectly logical and reasonable deduction.

It is reasonable in the sense that one of the greatest advantages of common law judges has been their ability to lay down general principles capable of meeting the ever-changing circumstances in an ever-changing society. It is this ability that permits a judge to play his proper function in seeing that the purpose of the law is carried out. It is true that only from hindsight can one say that the principle stated above enabled our recognition rules to take into account changing circumstances-i.e., statutes changing domestic jurisdiction; but certainly we cannot deny Lord Watson that foresight.

Lord Watson was concerned that, as much as possible, the scandal referred to by Lord Penzance in Wilson v. Wilson should be avoided. One 
of the ways it could be avoided was for all courts to exercise jurisdiction on the basis of domicile. But what about a decree granted on some basis other than domicile? Surely, Lord Watson's attitude would be that such a divorce should be recognized in as many countries as possible. This result could only be achieved if it would be recognized in other countries that exercised jurisdiction in like circumstances. Furthermore, Lord Watson was probably very much aware of the fact that, in the future, various countries might see fit to have their courts exercise jurisdiction on some basis other than domicile of the parties. It is not unreasonable to suggest that Lord Watson was formulating a general principle to meet those future exigencies. For this reason it is submitted that the conclusion reached above is warranted and reasonable. At any rate, it can be definitely said that Lord Watson was not laying down the test of domicile of the parties at the commencement of the proceedings as the exclusive test for recognition of foreign decrees.

Subsequent cases ${ }^{15}$ in England and the Commonwealth have not found it necessary to analyze critically Lord Watson's judgment; it was enough to state that it decided that a foreign decree would be recognized if the parties were domiciled within the jurisdiction of the foreign court. Certainly that was enough when the only basis for domestic jurisdiction was the domicile of the parties, or when the facts did not give rise to any other basis for recognizing the decree. Yet, those case ${ }^{16}$ and the decision of Le Mesurier v. Le Mesurier are cited for the proposition that the domicile of the parties within the jurisdiction is the only basis upon which a foreign divorce decree will be recognized. It is submitted that the general principle laid down by Lord Watson has never been overruled; it simply has not been necessary to rely upon it in the past. Granted, it was strictly a dictum, but nevertheless it deserves the same weight that the rest of his dictum has been given in subsequent cases.

Therefore, it can confidently be stated that when divorce jurisdiction statutes were passed by various countries, the state of the common law rules for recognition of foreign decrees was as follows: the decree of a foreign court would be recognized in a Commonwealth court if, at the time of the commencement of the proceedings, the parties were domiciled within the jurisdiction, or if the Commonwealth court would have exercised jurisdiction in similar circumstances.

It is proposed now to analyze critically cases subsequent to the passing of such statutes to see what approach the courts have taken towards this problem.

As early as 1921, Mr. Justice Irvine, by way of obiter, in the case of Chia v. Chia, ${ }^{17}$ expressed doubts whether a divorce granted in the state of Victoria, when the parties were not domiciled there, would be recognized in foreign courts. The Court of Appeal of New Zealand, again by way of obiter, expressed the same doubts in Worth v. Worth. ${ }^{18}$ However, it should be pointed out that at this time, so-called "deserted wife" legislation was not nearly so prevalent as it later became. Therefore, the

15 No attempt will be made here to list them, for the cases are numerous.

16 Ibid. See Tuck, Correspondence, 23 Can. Bar Rev. 224, (1945).

17 [1921] V.L.R. 566, 575.

18 [1931] N.Z.L.R. 1109 (C.A.). 
doubts of these courts were justified, for, in point of fact, there was little likelihood at that time that such decrees would be recognized elsewhere.

A rule of domestic jurisdiction based on the domicile of the parties, combined with the rule that the fiction of unity of husband and wife still persists and prevents a wife from acquiring a domicile of her own, ${ }^{19}$ proved to be a worker of injustice and hardship on deserted wives. ${ }^{20}$ In modern times, mobility has increased to a vast extent and the incidence of husbands leaving their wives and families for a foreign country is not insignificant. The second world war period plainly exposed the hapless situation of the deserted wife. The rationale behind domicile as the test for domestic jurisdiction had to give way to some extent.

Thus, in Canada, as a direct result of the Cook ${ }^{21}$ case, the Parliament of Canada passed the Divorce Jurisdiction Act, ${ }^{22}$ in a half-hearted effort to provide some relief for the deserted wife. In England, the Matrimonial Causes Act, $1937,{ }^{23}$ was passed offering substantially the same relief as our Divorce Jurisdiction Act. (In more recent times the Parliament of the United Kingdom has seen fit to extend the domestic jurisdiction of its courts even further. Section 18 of the Matrimonial Causes Act, 1950,24 now permits the wife, who has been resident in England for three years preceding the commencement of the proceedings, to petition for a divorce. Most of the other Commonwealth nations ${ }^{25}$ also have legislation permitting a wife to obtain a divorce even though the husband is domiciled elsewhere at the commencement of the proceedings. In the United States of America, it has long been held that a wife could acquire a separate domicile in appropriate circumstances. ${ }^{20}$ ) It therefore became a matter of major importance to determine what status a decree of divorce granted pursuant to those statutes would be given in other countries.

The first case purporting to explain the effect of this legislation was Warden v. Warden, ${ }^{2 i}$ a case from Scotland. In that case the parties were married in the District of Columbia, United States, in October, 1937. They separated in 1945 and the wife obtained a divorce in the state of Nevada on January 15, 1947, the court proceeding on the basis of six weeks' residence and the domicile of the wife within the jurisdiction. The husband was never domiciled in Nevada. In 1950 the wife remarried and the husband then brought an action for divorce in Scotland, claiming that the decree granted by the Nevada court was invalid as he was not domiciled in Nevada at the time of the commencement of the proceedings. It did not appear that the wife had been resident in Nevada for three years prior to the proceedings, but it was argued, on her behalf, that the passing of the Law Reform (Miscellaneous Provisions) Act, $1949^{28}$ enabling the courts of Scotland to entertain proceedings in divorce on the basis of three years residence of the wife, required the Scottish courts to recog-

10 As lald down in A-G. Alta. v. Cook, [1926] A.C. 444; (1926) 1 W.W.R. 742; [1926]

20 For a sood discussion on thls polnt see, Graveson, Conflict of Laws in Matrimonial Causes, 3 Int. L.Q. 371 . (1950).

21 Ante, n. 19 .

21 Ante, n. 19.

28 (Imp.) 1 Edw. VIII \& Geo. VI, c. 57, s. 13.

28 (Imp.) 1 Edw. VMI \& Geo. VI,

28 (Imp.) 14 Geo. VI, c. 25, 8. 18.

26 As early as 1869, the Supreme Court of the United States in Cheever v. Wilson, 9 Wall 108,124 , said "The rule is that she may acquire a separate domicile whenever it is necessary or proper that she should do so".

27 [1951] S.C. 588.

38 (Imp.), 12, 13 \& 14 Geo. VI, c. 100. 
nize divorces granted upon a similar basis. This contention was rejected in no uncertain terms by the Lord Ordinary, Lord Strachan, delivering the judgment of the Outer House.

Substantial portions of Lord Strachan's judgment will be cited here because it presents clearly and concisely the argument of those who feel the conflict rules for recognition of foreign decrees have not been changed by statutory enactments changing domestic jurisdiction. He says, at page 509:

Ever since the case of Le Mesurier [1895] A. C. 517, the general rule which has been accepted by the Court of Session is that jurisdiction in divorce belongs only to the Courts of the permanent domicile of the husband. That is still the general rule upon which the Court of Session assumes jurisdiction. There are exceptions to that rule, and in my opinion, section 2 of the Act of 1949 constitutes an exception enacted by Act of Parliament for the specific purpose of giving a wife a right of action in Scotland notwithstanding that her husband is not domiciled in Scotland, but subject to special conditions. Except in so far as otherwise provided by statute, the Court of Session, in my view, is bound by judicial precedent to apply the general rule not only in asserting jurisdiction for itself by also in determining the validity of foreign decrees. The Act of 1949, extends the jurisdiction of the Court of Session, but it makes no provision whatever in regard to the recognition of foreign decrees. Had it been the intention of Parliament that the law as to the recognition of foreign decrees should also be changed, some provision to that effect would have been made.

It should be noted that Lord Strachan's view of the effect of the Act was shared by all the leading authorities ${ }^{20}$ in the conflicts of laws. Graveson, Cheshire, Dicey and Falconbridge were all of the opinion that the rule as laid down in Le Mesurier was not changed by the various Acts. Indeed, it was this very conclusion that prompted their insistence on the establishment of a more realistic position with regard to the recognition of foreign decrees, and the domicile of the wife. ${ }^{30}$ Graveson said:

Such being the case, little prospect exists at present of English "residence" decrees [deserted wife] being recognized in the Canadian provinces, or in the Australian states, since, ironically enough the latter follow closely English decisions. Judicial distrust of legislation can be carried to extremes. ${ }^{31}$

The case of Fenton v. Fenton ${ }^{32}$ confirmed Graveson's doubt at least so far as the state of Victoria is concerned. In that case the court refused to follow Travers v. Holley, ${ }^{33}$ showing a preference for Lord Strachan's reasoning in Warden v. Warden. ${ }^{34}$ In fact his judgment was cited extensively therein.

It is the writer's view that if the general principle, as enunciated by Lord Watson and as indicated previously, is not acceptable, then the reasoning of Warden v. Warden is decisive on the point. For if it is admitted that the rule for recognition was historically confined to the domicile of the husband at the commencement of the proceedings, by what process of reasoning does a statute that is confined solely to changing the domestic jurisdiction of the courts also change its recognition rules? An intention to change those rules cannot be imputed to the legislature, because in the past, Parliament, when desirous of changing the conflict rules, has taken care specifically to indicate that intention.

29 Falconbridge, ante, n. 10 at 744 (even after the discussion in Travers v. Holley.) Dicey, ante, n. 10 (6th ed.) at 375-376; Graveson, ante, n. 20; Cheshire, (1945) 61 L.Q. Rev. 352, 368; Morris, (1946), 24 Can. Bar Rev. 73, 82-83.

30 Ibid.

31 Ante, n. 20.

32 [1957] $\stackrel{\text { V.R. }}{ } 17$.

83 Ante, n. 5 .

84 Ante, n. 27. 
In this regard reference may usefully be made to the Legitimacy Act, 1926. ${ }^{35}$ Unitil 1926 there was no such thing as legitimation within England.

The 1926 Act provided that legitimation would be possible in England if the father were domiciled in England at the time of the marriage. But the statute did not stop there. It went on to indicate that a child would be recognized as legitimate in England if legitimation were possible by subsequent marriage in the domicile of the father at the time of marriage. In other words, the common-law (Wright-Grove) recognition rule was expressly changed. Other examples of Parliament making its intention clear when desirous of changing or retaining conflict rules are the Matrimonial Causes (War Marriages) Act, 1944, ${ }^{36}$ and the Marriage (Enabling) Act, $1960 .^{3 i}$

It is the writer's view, therefore, that it is not possible to maintain the proposition that the Divorce Jurisdiction Act has implicitly changed our conflict rules in Canada. ${ }^{37 a}$ If we will now recognize divorces granted by the domicile of the husband immediately prior to the commencement of two or more years of desertion, we will do so on the basis that the common law always has been that our recognition rule is a reflection of our domestic rule.

Dean Griswold ${ }^{38}$ has indicated that Le Mesurier certainly did not decide otherwise. He argues that those who found themselves on Le Mesurier for the proposition that the domicile of the parties is the exclusive common law test for recognition of foreign divorce decrees for all time, misunderstand what that case actually decided. He suggests that if Le Mesurier did decide that domicile is the exclusive test, which in his opinion is not clear, then that part of the decision was only a dictum. It must be a dictum, for the Court would be deciding what the rule should be even in the event of the passing of legislation changing the domestic rule- circumstances which were not before the Court at that time. He points out that until such legislation was passed it remained an open question what the common law rule for recognition would then be. He indicates that the common law, with its great capacity for growth, when confronted with this new set of circumstances would fall back on general principles and provide a just and reasonable solution. It is the writer's submission that the general principle which the Court is to fall back upon is to be found in Lord Watson's judgment itself; namely, that our recognition rule is a reflection of our domestic rule. The important point which Dean Griswold makes is that Le Mesurier cannot stand for the proposition that the domicile of the parties is the exclusive common law test for all time.

Having examined the approach of the courts of Scotland and Victoria, what is the position of the English courts? The first English case on point was Travers v. Holley, ${ }^{30}$ a case which has received so much attention in recent times that it is hardly necessary to relate the facts. It will suffice to indicate that the parties were married in England in 1937 and shortly thereafter migrated to New South Wales. In 1940 the hus-

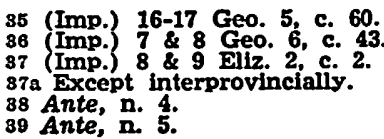


band left his wife, and in 1941 he joined the Australian Armed Forces. In 1943 the wife filed a petition for divorce in New South Wales. A decree of divorce was granted, the court proceeding on the basis of section 16 (a) of the New South Wales Matrimonial Causes Act. ${ }^{40}$ That Act provided that, where the wife had been deserted continuously for three years, she could bring an action for divorce and would not be deemed to have lost her domicile by reason of her husband having thereafter acquired a foreign domicile. The husband subsequently petitioned for a divorce in England on the basis that the decree of divorce granted by the New South Wales court was invalid, he not being domiciled there at the commencement of the proceedings.

The majority in the Court of Appeal, Lords Justice Somervell and Hodson, found that the husband had acquired a domicile of choice in New South Wales and found it unnecessary to decide whether he had abandoned that domicile of choice by the time of the commencement of the proceedings. They held that an English court would recognize this decree on the basis of reciprocity. The New South Wales legislation was substantially the same as the provisions for the deserted wife in the 1937 Matrimonial Causes Act and therefore a decree granted pursuant to it would be recognized. Here we have the introduction of what was thought to be a startling innovation in our rules for the recognition of foreign decrees of divorce.

However, on reference to the judgments we can see that the Lords Justice did not feel that it was startling in the least. Somervell, L. J., says at page 250:

On principle it seems to me plain that our courts in this matter should recognize a jurisdiction which they themselves claim. I did not, myself, really understand on what grounds it was submitted that the result should be otherwise.

He then goes on to state the general principle laid down by Lord Watsonthat we will not recognize a foreign decree when it is based on rules peculiar to its own forum-and says:

Applying this principle, the provisions of the New South Wales Act of 1879 are since 1937 no longer, so far as our courts are concerned, peculiar to its forum, but are common to its forum and our own.

It was argued by counsel that the rule laid down as to domicile by Le Mesurier was decisive in the case. Hodson, L. J., in answering this argument, said, at page 255:

It seems to me, therefore, that Parliament has cut the ground from the argument put forward on behalf of the husband. If English courts will only recognize foreign decrees of divorce where the parties are domiciled in the territory of the foreign court at the time of the institution of the proceedings, because that is the jurisdiction which they themselves claim, what is the situation when the courts of this country arrogate to themselves jurisdiction in the case of persons not domiciled here at the material date? It must surely be what entitles an English court to assume jurisdiction must be equally effective in the case of foreign court.

It should be noted that when Hodson, L. J., speaks of the courts "arrogating" to themselves jurisdiction, he is clearly wrong, for the court has no choice in the matter. However, it is submitted that this was not material to Hodson, L. J.'s reasoning; for his judgment was certainly not

401899 No. 14, 8. 16. 
founded on that premise but rather on the general principle laid down by Lord Watson in Le Mesurier (as was Lord Somervell's judgment).

Lord Justice Jenkins dissented on the facts, finding that the husband never had been domiciled in New South Wales, but otherwise agreed with the disposition of the case, "having regard to the terms of s. 16 (a) of the New South Wales Matrimonial Causes Act, 1899, and s. 13 of our own Matrimonial Causes Act 1937".

That case established for England the proposition that, where the legislation under which the foreign court assumes jurisdiction is in substance the same as England's, then divorces granted pursuant to that legislation will be recognized in England regardless of the husband's domicile. Although the case made a great stride in the right direction, it is still subject to severe criticism.

All the judges indicated that the legislation was in substance similar, and based their judgment on that fact. This caused Hodson, L. J., to introduce the notion of reciprocity. There is no such thing as reciprocity or comity in the recognition of foreign judgments, and it was wholly unnecessary to introduce this misleading term. The fact of the matter is that, once legislation has changed the domestic jurisdiction, there exists, on the basis of Le Mesurier a new ground upon which to recognize foreign decrees. The rule in the Travers case should be stated simply as follows: an English court will recognize a decree of a foreign court if the husband was domiciled within the jurisdiction immediately preceding the commencement of the desertion. There was no need to introduce any notion of reciprocity; the issue is simply whether the husband, on the facts, was domiciled within the jurisdiction immediately preceding the commencement of the desertion, (just as the issue in the usual case where there is no desertion or change of the husband's domicile is simply whether the husband was domiciled within the jurisdiction at the commencement of the proceedings). Where that test is satisfied investigation should come to an end. Under the ordinary rule once it is found that the husband was domiciled in Nevada at the relevant time, it should be of no concern that the Nevada court proceeded on the basis of six weeks residence. Likewise, under this new rule it is unnecessary to examine the legislation to see on what basis the foreign court proceeded.

The error of comparing statutes was continued in the subsequent cases of Dunne v. Saban ${ }^{41}$ and Carr v. Carr ${ }^{42}$ The case of Arnold v. Arnold purported to give the rule too wide an effect by stating that in order to recognize a foreign decree it is not even necessary that an English court would exercise jurisdiction on the facts that faced the foreign court.43 It was not until Robinson-Scott v. Robinson-Scott ${ }^{44}$ that proper effect was given to the rule. These cases will now be considered in detail.

In Dunne v. Saban the wife obtained a divorce in Florida on the basis of her separate domicile and ninety days residence. The husband was

41 [1954] 3 W.L.R. 980. [1954] 3 All E.R. 586.

42 [1955] 2 All E.R. 61.

43 Kennedy in his earlier articles felt that similarity of legislation was needed but then reversed his field later and purported to give the doctrine too much effect. See reversed his" field later and purported to give the doctrine too much effect. See "Reciprocity" in the Recognition of Foreion Judgments, 32 Can. Bar Rev. 359, 362 and

4t [1957] 3 W. L.R. 842, [1957] 3 All E.R. 473. 
domiciled in England at all material times. On the facts, the wife had been resident in Florida for a little more than two years. Counsel argued that Travers v. Holley should be applied. Mr. Justice Davis replied:

It seems to me that the observations of the Court of Appeal ... were directed to a case where the extra-ordinary jurisdiction ... of the foreign court corresponds almost exactly with the extra-ordinary jurisdiction exercised by this court.

Davis, J., is clearly justified in his interpretation of Travers v. Holley; but nevertheless, he was perpetrating an error by not confining himself to an examination of the facts before him to see if the recognition test was satisfied. In any event, even if the proper approach had been taken, the result would have been the same, since the wife had not resided in Florida for three or more years prior to the commencement of proceedings.

In Carr v. Carr the wife had obtained a decree of divorce in Ireland under the deserted-wife legislation that corresponded in its terms exactly with the 1937 Matrimonial Causes Act. The husband was not domiciled in Ireland at the time of the proceedings. Jenkins, J., with no discussion of the problem at all, followed Travers v. Holley on the basis that the legislation was the same. His examination should have been restricted to the facts.

In Arnold v. Arnold, ${ }^{45}$ an Englishman domiciled in England married a Finnish woman in England in 1922. They moved to Helsinki and became domiciled there. In 1930 the husband deserted his wife. She brought suit for divorce and was granted a decree, the Finnish courts exercising jurisdiction on the basis that Finland was the principle place of residence of the parties. The husband brought an action in England for a declaration that the decree was valid.

Mr. Commissioner Latey held that it was a valid divorce, purporting to follow Travers v. Holley. But he went further than that case, as is evidenced by the following comment:

The fact that only six weeks or ninety days residence suffices in certain states in the United States of America to found jurisdiction seems to me to be beside the point if in fact there had been say two years residence or more, or even less, if the residence is genuine and bona-fide and not merely for the purpose of getting a divorce in a convenient court.46

$\mathrm{He}$ is right in his approach as far as looking to the facts of the case is concerned, but he is clearly wrong in suggesting that less than three years residence prior to the proceedings is required in order for the divorce to be recognized in an English court.

It is the writer's suspicion that Mr. Commossioner Latey's error resulted from a further error he made in the case. The Finnish court would not grant a divorce on the basis of desertion unless the country of the husband's domicile would also grant a divorce on the basis of desertion. Mr. Commissioner Latey compared this with the English ground for divorce after three years' desertion. Of course the grounds were not similar in length of time and therefore he suggested that the Travers $v$. Holley principle did not require them to be. The whole point is that it was unnecessary for him to investigate the grounds for divorce. For in a recognition case, it is not a comparison of grounds of divorce that is

45 [1957] 2 W.L.R. 366, [1957] 1 All E.R. 570.

40 Id. at 378. 
involved at all; it is simply a matter of the recognition rule being satisfied on the facts. Here, all that was material was whether the wife had been resident in Finland for three years prior to the proceedings. She clearly was and therefore that was an end of the matter.

The next case is Robinson-Scott $v$. Robinson-Scott, ${ }^{47}$ which was instrumental in enunciating the correct principles to be adopted in this area. The parties were married in Switzerland in 1950; the husband was at the time domiciled in England and the wife had been domiciled and resident in Zurich since 1943. After a short time the husband returned to England. In 1953 the wife was granted a divorce by the District Court of Zurich on the ground that the matrimonial relations were deeply and irreparably disrupted. The court exercised jurisdiction on the basis that the wife had acquired a domicile of her own according to the laws of the Canton. In 1957 the husband presented a petition in England for a declaration that the marriage had been validly dissolved.

Karminski, J., in the course of his judgment very properly indicated that there clearly was no similarity of legislation involved here as the Swiss court had exercised jurisdiction on the basis of a separate domicile of the wife, a concept completely strange to English law. He stated the critical issue at page 849 .

I believe that the true question to be answered in this case is whether the courts of this country can recognize a foreign decree where, in fact, the wife was resident in the territory of the foreign court for three years immediately preceding the commencement of the proceedings there, even though the jurisdiction of the foreign court was based on different grounds. [Emphasis added]

The learned judge went on to examine exhaustively the cases in point and found no direct binding authority. In answering the question propounded, he fell back on the theory conceived by Dean Griswold to the effect that it is the factual circumstances of the case, and not a comparison of legislation, which is the determining factor. For the reason suggested earlier it is the writer's view that this is the correct approach.

The judgment is significant in another respect, for it also indicates how far the rule is to be carried. In the Arnold ${ }^{48}$ case, $\mathrm{Mr}$. Commissioner Latey felt that three years was not required. Kenned $y^{40}$ also thought the principle was not so restricted. Karminski, J., clearly points out that it is so limited. He says at page 849 :

Whatever may have been the motive of the legislature in insisting on three years residence under section 18 (1) (b) of the Matrimonial Causes Act, 1950, I cannot agree with $\mathrm{Mr}$. Commissioner Latey that the period of residence demanded by the law of a foreign court to found jurisdiction is immaterial. If similarity is the basis of recognition, there must be similarity in fact though not in terminology.

It is clear that his conclusion is logically correct. If we have an additional test for the recognition of foreign decrees what is that test? On the principle that the test is a reflection of our domestic rule, it is, in this case, residence in the jurisdiction for three years preceding the commencement of proceedings. That is the test; nothing more is required; nothing less will be acceptable. 
It is submitted that the cause of confusion is the use of the word "reciprocity" in Travers v. Holley. This term naturally misleads one into believing substantial similarity per se is sufficient. But on the principle of Le Mesurier, once England passed the Matrimonial Causes Act, 1937, it then had an additional test for the recognition of foreign decrees. That was so regardless of whether any other country in the world had "deserted wife" legislation. The rule did not spring up as soon as some other country passed similar legislation; it was only then that it was more important. But if the principle of reciprocity plays a part, then we are saying that the rule springs up when legislation similar to our own is passed in other countries. In other words, other countries determine our conflict rules. Surely this cannot be true.

Karminski, J.'s view on this point was confirmed in Manning v. Manning. ${ }^{48 \mathrm{a}}$ In that case $\mathrm{Mr}$. Commissioner Latey resiled from the position he had taken earlier in Arnold v. Arnold, ${ }^{\text {so }}$ and said at page 259:

I am content to follow the principle which Karminski, J. had laid down, that is, that there must be at least three years residence to found jurisdiction whereever the action is brought.

He also indicated that Karminski, $J$. had pointed out that the ground upon which the divorce was granted is immaterial and that an investigation in that direction is unwarranted. Clearly then, the Robinson-Scott case and the Manning case have finally put the law of recognition of foreign decrees in England on its proper basis.

Having examined the opposing views outside of Canada on the effect of Acts creating domestic jurisdiction in divorce, it now remains to examine the position in Canada.

The question was first broached in La Pierre v. Walter. ${ }^{.1}$ In that case one Walter, who was at all material times domiciled in Alberta, married in Scotland in 1944. On October 3, 1953 the wife was granted a decree of divorce in Scotland on the ground of desertion, and the court exercised jurisdiction on the basis of three years' residence. Walter remarried in Alberta and the wife of the second marriage brought an action for a decree of nullity in the Trial Division of the Supreme Court of Alberta. It is obvious that the Alberta Court could not recognise this divorce even if the domicile of the husband immediately prior to the commencement of two or more years' of desertion were to be regarded as an additional test for the recognition in Canada of foreign decrees, since the husband at no time had been domiciled in Scotland. However, Mr. Justice Riley, in a dictum, took it upon himself to consider whether a divorce granted in circumstances under which the Alberta court would have exercised jurisdiction would be recognized in Canada. He examined the English and other authorities and came to the following conclusions:

I have not been able to discover any Canadian decisions with respect to to these various statutes, and with respect to the principle as enunciated in Travers v. Holley. Doubt however, has been expressed as to the correctness of those decisions, and I do not quite understand how a decree of divorce pronounced by a court whose jurisdiction is solely derived from some rule of municipal law made by it, need be recognized by the courts of this jurisdiction, even if such recognition is said to be founded on some vague notion of reciprocity ... As the defendant had never been domiciled in Scotland, and as I prefer the rea-

49a [1958] 1 All F. R. 291.

51 (1960), 1 W.W.R. 40 . 
soning of Fenton v. Fenton, and Warden v. Warden, to that in Travers v. Holley ... and as the law of Canada does not contain any provision recognizing foreign decrees, and as there is no statutory jurisdiction permitting this court to assume jurisdiction on the basis of three years residence only of the wife within the jurisdiction of this court, as far as this court is concerned the marriage of the defendant to Elizabeth Dose has never been lawfully dissolved. . . .52

It was not long before his brethren expressed a contrary view. In Bednar \& Bednar v. Deputy Register General of Vital Statistics, ${ }^{53}$ Bednar had married in Czechoslovakia in 1927 where he was domiciled. In 1951 his former wife brought an action for divorce in Czechoslovakia, where she was domiciled before marriage and resident all her life. The court granted a decree on the grounds of desertion and adultery but it did not appear on what basis they exercised jurisdiction.

\section{Mr. Justice Milvain in a rather brief judgment said:}

Under the Divorce Jurisdiction Act, R.S.C. 1952, c. 84, a wife deserted in Canada, under similar circumstances to those related has access to our courts. As our court exercises a jurisdiction on the same basis as would a Czechoslovakian court, and as the divorce in question was granted on the same grounds as would be done in our courts, it would seem strange to me were we not to recognize such a divorce. ${ }^{5 t}$

He cites the decision of Travers v. Holley and says that on the principle of comity and reciprocity the decree should be recognized.

If $\mathrm{Mr}$. Justice Milvain is suggesting in the above passage that the grounds of the divorce have to be the same, he is clearly wrong for the reasons indicated earlier. Furthermore, his use of the words reciprocity and especially comity are wholly unecessary. They tend to mislead and confuse.

Pledge v. Walterss was a case involving the same Walter as the one in La Pierre v. Walter. ${ }^{.0}$ He had married again and the wife brought suit for a decree of nullity. Mr. Justice Primrose chose not to dispose of the case in the same manner as Mr. Justice Riley had.

There will be a decree but I prefer to put it on a different ground than the learned judge in the previous action. We respect foreign decrees based on provisions similar to our own by reason of the fact that we ourselves will grant a decree in those circumstances. ... In this case the courts of Alberta where the parties are domiciled would not recognize the Scottish divorce on the ground of desertion, and consequently the first marriage of the defendant husband is valid and subsisting'.

The conclusion reached by $\mathrm{Mr}$. Justice Primrose was the correct one; but, with all due respect, his reasoning is fallacious. As has been indicated above, a comparison of the grounds of divorce plays no part in the recognition of foreign judgments. Karminski, J., in the Robinson-Scott ${ }^{57}$ case and Kirby, J., in Re Allarie, ${ }^{58}$ (to be considered shortly) emphasized this point. On the other hand, it can be taken from the learned judge's opening remarks that he does support the proposition that divorces granted in circumstances in which our courts would exercise jurisdiction will be recognized in Alberta.

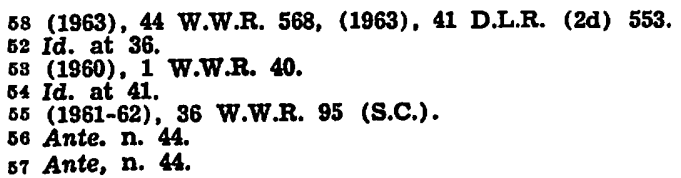


In Re Allarie's License Application, ${ }^{59} \mathrm{Mr}$. Justice Kirby was confronted with the problem and delivered a carefully considered judgment. The applicant, domiciled in Canada, married an Englishwoman in England in September, 1946. He returned to Canada in 1946 but when his wife did not join him as expected, he went back to England in 1951. In 1952 he deserted his wife and remained in England until 1957, at which time he returned to Canada. In April, 1963, the wife was granted a decree of divorce in England on the grounds of desertion and the court exercised jurisdiction on the basis that the husband was domiciled in England immediately prior to the desertion.

Mr. Justice Kirby, fully aware of the significance of the issue before him, set out the arguments that have been advanced on both sides of the issue; and, distinguishing the judgment of Riley, J., in La Pierre v. Walter, ${ }^{60}$ chose to follow the reasoning of Travers $v$. Holley and the general principle laid down by Lord Watson in Le Mesurier v. Le Mesurier.

It is interesting to note that, although $\mathrm{Mr}$. Justice Kirby did not so indicate, he adhered to the principle of the Robinson-Scott ${ }^{01}$ case. For, unlike the Divorce Jurisdiction Act, ${ }^{62}$ the English Matrimonial Causes Act, $1937^{63}$ does not stipulate that the wife must be deserted for two years before she can bring her action. Therefore, in result, the case stands for the proposition that we look to the facts to see if in fact the wife has been deserted for two years or more, and do not compare statutes.

The recent case of Januskiewicz v. Januskiewicz ${ }^{04}$ in the Manitoba Court of Queen's Bench is a useful one. In that case, the husband and wife were domiciled in Poland in $\mathbf{1 9 5 8}$ when the husband left for Canada. In 1964 the wife obtained, in Poland, a divorce on the ground of desertion. The husband sued in Manitoba for a declaration that his marriage had been validly dissolved, and the declaration was granted. It is worthy of note that Nitikman, J., had no difficulty in disposing of the matter of the grounds upon which the divorce was granted:

Once it is recognized the foreign court has jurisdiction to deal with the matter, it follows that a divorce granted by that court, on grounds proper to it, is valid, and must be so found by our courts. ${ }^{65}$

It is clear that the learned justice's ruling on the question of recognition of the Polish divorce was grounded-and properly so-on the facts:

In view, then, of the fact that both parties, immediately prior to the desertion of the defendant by the plaintiff, were domiciled in Poland; that such desertion continued for a period exceeding two years, and that at the time the defendant brought the action for divorce both parties were living separate and apart; and having in mind the provisions of the English and Canadian enactments hereinbefore referred to, ${ }^{60}$ I have no hesitation in holding that the Polish court had jurisdiction to hear the suit for divorce herein. ${ }^{67}$

Although the learned justice was not led astray by consideration of the foreign legislation or the grounds upon which divorce was granted his judgment is clouded by reference to "principles of comity and recip-

59 Ibid.

60 Ante, n. 51.

61 Ante, n. 44

62 Ante, n. 2.

63 Ante, n. 23.

64 (1966), 55 W.W.R. 73

65 Id. at 83 .

66 I.e., s. 13 of the Matrimonial Causes Act, 1937 I Edw. VII \& I Geo. VI, c. 57; and s. 2 of the Divorce Juridiction Act, (Can.) c. 84.

67 Ante, n. 64, at 80 . Emphasis Added. 
rocity,"0s which he derives from the judgment of Hodson, L. J., in Travers v. Holley. ${ }^{69}$ Had he referred to the Robinson-Scott case, that error might not have been made. His judgment is also harmed somewhat by a lengthy but unnecessary reference to the recent Supreme Court of Canada case of Schwebel v. Ungar, ${ }^{70}$ a case which is evidently destined to become a red herring-and an unsalted one at that-on the path of the development of our conflicts rules in regard to recognition of foreign judgments. Perhaps the reference to that case stemmed from a difficulty in fitting it into the environment of the orderly development of such rules; it was, in any event, not necessary.

A recent case not directly in point, but nonetheless of some value is Re Capon. ${ }^{71}$ In that case the Ontario Court of Appeal considered the validity of a foreign decree of nullity. The Court held that the facts of the case were such that, had they arisen in Ontario, the Ontario courts would have assumed nullity jurisdiction; and that therefore the Ontario courts should recognize the foreign decree. This was the same broad approach to recognition as was stated by Lord Watson in Le Mesurier v. Le Mesurier, applied by the Court of Appeal in Travers v. Holley, and explained in Robinson-Scott v. Robinson-Scott. The approach was the same, and the reason (namely, the undesireability of causing persons to be regarded as married in one jurisdiction and unmarried in another) was also the same, as is evident from the following passage in the judgment of Schreoder, J. A.:

In my view the assumption of jurisdiction by the English Courts in the case of a void marriage is founded on sound reason, for if a void marriage is a complete nullity and can properly be regarded in that light by every Court and by all persons, there can be no valid reason for withholding recognition from a decree recording its non-existence made by the forum of the country in which only one of the parties is domiciled. To restrict jurisdictional recognition to the Courts of the country of the common domicle would result in the creation of an intolerable situation in the case of a void marriage where the domicle of the parties, as has been demonstrated, may be different. In such a case the problem of jurisdiction would be hopelessly insoluble, leading to the creation, as in the case at bar, of a deplorable condition in which one of the parties would be regarded as married in one country and unmarried in another.

I have formed the view that the Courts of Ontario would be entitled to assume jurisdiction on the ground that the petitioner alone is domiciled in this Province whether the marriage was celebrated here or not. To deny the equivalent right to a foreign Court would be inconsistent and contrary to well recognized principles. In Travers v. Holley, (1953) P. 246, the Court of Appeal gave effect to the rule that what entitles an English Court to assume jurisdiction is equally effective in the case of a foreign Court. ${ }^{72}$

While the extension of the proper Travers v. Holley rule beyond the bounds of recognition of foreign divorces may be open to question, ${ }^{73}$ it is clear that the Ontario Court of Appeal in Re Capon was viewing the rule in Travers v. Holley in its proper aspect insofar as recognition of foreign divorce decrees is concerned.

68 Id.

69 [1953] P. 246, 256; [1953] 3 W.L.R. 507.

70 [1965] S.C.R. 148, In that case, the Supreme Court made a rather signiflcant error by confusing the rules as to the capacity of persons to enter into marriage with the rules as to recognition of foreign divorces. The two rules are quite distinct and the former can have no proper bearing on a problem that relates purely to recognition of foreign divorces.

71 (1965) 49 D.L.R. (2d) 675.

72 Id. at 687-688.

78 The writer sees no point to discussing in this paper whether or not it is open to questlon. 
From the above analysis it appears that the weight of authority in Canada supports the view that we now have an additional rule for the recognition of foreign judgments in Canada. Until we have a pronouncement from a Court of higher authority we shall have to proceed upon that basis.

It is the writer's view that the Supreme Court of Canada would uphold this view upon a critical analysis of the reasons behind Lord Watson's judgment in Le Mesurier v. Le Mesurier. Lord Watson was concerned that decrees of divorce should be universally recognized. With this proposition surely no one will quarrel, for it is a highly important consideration when the property rights of the parties and often the legitimacy of the children of the marriage are involved.

In Lord Watson's time how was the universal recognition of divorces to be achieved? It was to be achieved, taking the case of Ceylon as an example, if the court exercised jurisdiction on the basis of domicile. For then it would be exercising a jurisdiction based on rules that would be recognized by all countries, according to the general law of nations. Considering the desireability of having divorces universally recognized (upon which Lord Watson placed so much emphasis) and also the fact that so many countries now have "deserted wife" legislation, isn't it important that such divorces which all have the same element in common, namely, a desire to remedy the hardship of the deserted wife, should be recognized in those respective countries? If the principle laid down by Lord Watson is followed, it is surely possible to do so. If such divorces are recognized, the need for treaties and mutual legislation contemplated by Falconbridge and other writers before the decision in Travers v. Holley will be avoided. The common law has shown its ability to meet new circumstances in many other areas, and Travers v. Holley and subsequent decisions simply exemplify that ability. To deny it is to deny the courts their proper function in carrying out the purpose of the law.

In summary then, what are the tests, at present, for recognition of foreign decrees in Canada? First, we still have our historical test of domicile of the parties at the time of the commencement of the proceedings. Secondly, there can be no doubt that as between the provinces, the domicile of the husband immediately preceding the commencement of two or more years' desertion constitutes an alternative additional test. Thirdly, it can be said with some degree of confidence that Canadian courts will recognize a decree of divorce granted by a foreign court where on the facts of the case the husband was domiciled within that foreign jurisdiction immediately preceding the commencement of two or more years' of desertion. Fourthly, and lastly, Canadian courts will recognize a decree of divorce granted in a foreign country if the courts of the domicile of the husband at the time of the commencement of the proceedings will recognize the divorce. 